\title{
Niet langer behoren de universitaire medische centra het primaat te hebben bij de opleiding van specialisten*
}

\author{
J.W. Briët
}

Hoewel historisch gezien de verantwoordelijkheid voor specialistenopleidingen berustte bij de medische faculteiten is het primaat van de universitaire medische centra (umc's) door ontwikkelingen in de tweede helft van de 20e eeuw achterhaald. Niet-universitaire ziekenhuizen zijn, onder andere door fusies, groter geworden en er werken meer specialisten, wier expertise op veel fronten niet onderdoet voor die van academische collega's en zij zijn voorzien van dezelfde kostbare medische apparatuur.

Coassistenten en artsen in opleiding tot specialist (AIOS'en) prefereren de opleiding in een niet-universitaire ten opzichte van een universitaire omgeving vanwege een grotere waardering voor het daar heersende onderwijsklimaat en meer gelegenheid om vaardigheid en kennis te verwerven. ${ }^{1}$ In academische ziekenhuizen wordt terecht veel aandacht besteed aan wetenschappelijk onderzoek en geavanceerde patiëntenzorg, maar dit gaat ten koste van onderwijs. Internationale acties om het universitaire medische onderwijs te redden getuigen zelfs van een dreigend faillissement. ${ }^{2-3}$ Verschuiving van de verantwoordelijkheid voor klinisch onderwijs heeft voordelen voor alle betrokkenen.

In het kaderbesluit van het Centraal College Medische Specialismen zijn in 2004 de opleidingseisen voor alle specialismen vastgelegd. ${ }^{4}$ (http://knmg.artsennet.nl, doorklikken op 'Opleiding en registratie'. Dit zijn deels disciplinegebonden eisen, deels alge- mene competenties. Deze betreffen de 7 rollen die een specialist moet kunnen vervullen: medisch handelen; kennis en wetenschap; communicatie; samenwerking; organisatie; maatschappelijk handelen; professionaliteit. $\mathrm{Al}$ deze rollen kunnen goed worden geoefend in niet-universitaire ziekenhuizen. Ook is er daar gelegenheid zich te bekwamen in de meeste disciplinegebonden eindtermen, omdat er minder selectie van patiënten is dan in de umc's. Tenslotte zijn het feit dat de meeste medisch specialisten werken in algemene ziekenhuizen en dat de opleiding er niet een is tot wetenschapper, maar tot praktische professional, extra argumenten om het primaat van onderwijs en opleiding niet langer bij de umc's te leggen.

Willen de algemene ziekenhuizen een voortrekkersrol bij de opleiding van specialisten waarmaken, dan kan niet worden volstaan met een uithangbord 'Opleidingsziekenhuis'. De 'teach the teacher'-trainingen zijn een goed, maar van meer belang is dat de door de AIOS'en aan patiënten bestede tijd aantoonbaar relevant is voor de opleiding. Het evenwicht tussen patiëntenzorg en opleiding moet worden herzien. ${ }^{5}$

Dat deze hervorming van de medische opleiding een aardverschuiving van het denken over het leren en het leven van de AIOS'en vergt, betekent dat de opleidingsziekenhuizen voor dezelfde uitdaging staan als de umc's in binnen- en buitenland. ${ }^{2-3} 5$ Ze zullen deze uitdaging zeker aannemen.

* Dit artikel verschijnt ook in het Nederlands Tijdschrift voor Geneeskunde. 


\section{Literatuur}

1. Boor K, Scheele F, Brölmann H, Schoot JTM van der, Velden L van der, Dorr P. Academie of periferie? Waardering door de leerling. Tijdschrift voor Medisch Onderwijs 2005;24:87-94.

2. Clark J. Five futures for academic medicine: the ICRAM scenarios. BMJ 2005;331:101-4.

3. Irby DM, Cooke M, Lowenstein D, Richards B. The academy movement: a structural approach to reinvigorating the educational mission. Acad Med 2004;79:729-36.

4. Besluit van de Minister van Volksgezondheid, Welzijn en Sport van 1 december 2004, nr. IBE/ BO-2535849, houdende de goedkeuring van het kaderbesluit en de 27 specifieke besluiten van het Centraal College Medische Specialismen. Staatscourant 2004: nr. 241.

5. Ludmerer KM, Johns MM. Reforming graduate medical education. JAMA 2005;294:1083-7.
De auteur:

Hr. dr. J.W. Briët, gynaecoloog, afd. Verloskunde, Deventer Ziekenhuis, locatie Geertruiden.

Correspondentieadres:

Hr. dr. J.W. Briët, Deventer Ziekenhuis, locatie Geertruiden, afd. Verloskunde, Postbus 5001, 7400 GC Deventer, j.w.briet@dz.nl.

Belangenconflict: geen gemeld.

Financiële ondersteuning: geen gemeld.

\section{Summary}

Historically, the training of specialist registrars, graduate medical education (GME), has been the responsibility of university teaching hospitals. Recent reforms of GME curricula and the increase in the number of district general hospitals (DGH) require a shift of the primacy of GME to the DGHs. These hospitals (DGH) will accept the challenge in order to fulfil their educational mission. (Briët J. University Teaching Hospitals should no longer hold primacy in graduate medical education. Dutch Journal of Medical Education 2006;25(3):145-146.) 